\title{
WIEDEŃCZYKA O WIELE WIĘCEJ ŁĄCZY Z MIESZKAŃCEM KRAKOWA CZY BUDAPESZTU, ANIŻELI Z MIESZKAŃCEM BERLINA. RECEPCJA RELACJI POLSKO- -AUSTRIACKICH Z PERSPEKTYWY „POLSKICH" ULIC W WIEDNIU
}

\section{Wstęp}

Historia Austrii jest od stuleci ściśle związana z przeszłością naszego $\mathrm{kraju}^{1}$. Bardzo trafnie wyraził ten stan rzeczy m.in. propagator polskiej kultury za granica, Wiedeńczyk Otto Forst-Battaglia (1889-1965), w słowach zacytowanych w tytule niniejszego artykułu, stwierdzając, że Wiedeńczyka łaczy o wiele więcej z Krakowianinem czy Budapeszteńczykiem, niż przykładowo z Berlińczykiem². Zresztą głębokie przekonanie o wewnętrznej wspólnocie duchowej, która istnieje pomiędzy wszystkimi ludami dawnej Monarchii Habsburgów jest istotnym motywem przeplatającym się przez całą twórczość m.in. tego publicysty i naukowca ${ }^{3}$. Wszak po dziś dzień aż około 2/3 Wiedeńczyków nie legitymuje się rdzennie austriackim

1 Życiem i działalnością Polaków w Wiedniu zajmowali się badacze wiedeńskich poloników już od pierwszej połowy XIX-tego wieku. Z opracowań przedstawiających całościowy obraz obecności naszych rodaków w stolicy Habsburgów warto tutaj przytoczyć następujące pozycje: R. Taborski, Polacy w Wiedniu, Wrocław 1992; J. Forst-Battaglia, Polnisches Wien, Wien / München 1983; E. Cwanek-Florek, Polnische Berühmtheiten im Spiegel der öffentlichen Erinnerung in Wien. Die Rezeption polnischer Spuren in der Donaumetropole, Marburg 2006; oraz F. Pesendorfer / G. Fischer, Wiener Impressionen. Auf den Spuren polnischer Geschichte in Wien, Wien 2002. Dokładną bibliografię dotyczącą tej tematyki przedstawia Cwanek-Florek (2006).

2 Za: R. Taborski, Polacy w Wiedniu, Wrocław 1992, s. 192.

3 Ibidem, s. 192. 
pochodzeniem. Stąd, przez całe stulecia, także Polacy czuli się dobrze w tak multietnicznym i multikulturowym mieście. Największy napływ naszych rodaków do Wiednia miał miejsce w okresie, gdy Galicja była jednym z jej krajów koronnych Monarchii, tj. w latach 1772-1918. I tak na początku XX wieku liczba Polaków w Wiedniu wynosiła 4726 osób s $^{4}$. A już w 1835 r. Jakub Franciszek Kluczycki podawał następujące czynniki, adekwatne dla ówczesnych realiów, dla których Polacy odwiedzają Wiedeń: zwiedzanie zabytków, w drodze do Włoch i z powrotem, kształcenie dzieci u najlepszych pedagogów, dla celów naukowych, dla służby publicznej, dworskiej czy wojskowej, w celach zarobkowych lub w związku z posiadłością położoną w stolicy Austrii ${ }^{5}$.

Wśród licznego grona Polaków masowo udających się do Wiednia były oczywiście również osobistości bardzo utalentowane, które na gruncie stolicy Monarchii Naddunajskiej dały się poznać z jak najlepszej strony. Niektóre z nich w tak dużym stopniu zapisały się w pamięć mieszkańców tego miasta, że ich działalność została uczczona trwałymi śladami w postaci m.in. 19 nazw ulic metropolii Habsburgów. Nazwy te nadano w większości w XX-tym wieku, lub -w mniej licznych przypadkach - u progu XX-tego stulecia.

Aby uporządkować rozważania na temat recepcji relacji polsko-austriackich z perspektywy "polskich" ulic w Wiedniu, zestawiono poniżej charakterystykę uczczonych postaci oraz genezę nadania nazwy ulicy $\mathrm{w}$ aspekcie grup zawodowych, które reprezentują uczczone osobistości. Tradycyjnie główne płaszczyzny działalności zawodowej to: polityka, gospodarka i kultura.

Największą liczbą ulic (13 nazw) uczczeni są Polacy reprezentujący świat kultury. Jest wśród nich czerech muzyków, także czterech naukowców, dwóch mecenasów sztuki, dwóch literatów oraz jeden architekt. Mniej licznie reprezentowani są politycy (3 nazwy). Co ciekawe, ich zasługi dla Austrii nie były identycznej skali: mianowicie jest wśród nich i legendarny pogromca Turków, Jan III Sobieski, i znany jedynie wąskiemu gronu specjalistów historyków Ludwik Possinger. Żaden z Polaków upamiętnionych w Wiedniu nazwą ulicy nie zajmował się gospodarką w ścisłym tego słowa znaczeniu. Natomiast trudno zaklasy-

${ }^{4}$ Według wyników spisu demograficznego przeprowadzonego w 1910 r. ludności niemieckojęzycznej było wówczas w Wiedniu 1726955 osób, Czechów - 98 461, Polaków - 4 726, Rusinów (dzisiejszych Ukraińców) - 1 432, Słoweńców - 1 118, Włochów - 973, Chorwatów - 377, Węgrów - 205, Rumunów - 123. Por. L. Stengelberger, Wiener Brauchtum des 19. und 20. Jahrhunderts in seinem mundartlichen Wortschatz, Wien 1968, s. 8.

${ }_{5}$ Por. J. F. Kluczycki, Pamiątki polskie w Wiedniu i jego okolicach. Jako też inne wiadomości tyczące się Polaków, szczególniej mieszkańców Galicji, Kraków, s. 311-323. 
fikować do którejś z powyższych grup legendarnego założyciela pierwszej wiedeńskiej kawiarni - jednak fakt ten niestety mija się z prawdą - J. F. Kulczyckiego.

\section{2. „Polskie" ulice w Wiedniu}

\subsection{Geneza nadania nazwy ulicy}

Nadanie wszystkich nazw ulic odbyło się oczywiście z inicjatywy austriackiej. W tabeli 1 zestawiono imiona postaci, które posiadają w Wiedniu swoje ulice nadane decyzją burmistrza (ulica Alberta), posiedzeniem rady miasta (ulica Borkowskiego) i uchwałami komisji rady gminnej (GRA III) z lat 1927-1973. Brak danych na temat organu nadającego nazwy w latach 60. XIX wieku.

Tabela 1. Data i organ nadający nazwę

\begin{tabular}{|l|l|}
\hline Nazwa ulicy & Data nadania i organ nadający nazwę \\
\hline Albertgasse & 27.12 .1862$, burmistrz, ulica przedłużona w 1905 \\
\hline Albertplatz & 1904 \\
\hline Borkowskigasse & 24.02 .1910$, posiedzenie rady miasta \\
\hline Curiegasse & 23.01 .1973$, komisja rady gminnej \\
\hline Czartoryskigasse & 18.07 .1894 \\
\hline Godowskygasse & 7.12 .1955$, komisja rady gminnej \\
\hline Gumplowiczstrasse & 15.04 .1959$, komisja rady gminnej \\
\hline Hubermanngasse & 7.12 .1955$, komisja rady gminnej \\
\hline Kiepura-Gasse & 12.05 .1975$, komisja rady gminnej \\
\hline Kolschitzkygasse & 1862 \\
\hline Kopernikusgasse & 1867 \\
\hline Leschetitzkygasse & 3.10 .1932$, komisja rady gminnej \\
\hline Lipinergasse & 21.06 .1961$, komisja rady gminnej \\
\hline Luxemburg Gasse & 5.01 .1927$, komisja rady gminnej \\
\hline Possingergasse & 1887 \\
\hline Rittnergasse & 28.09 .1960$, komisja rady gminnej \\
\hline Sobieskigasse & 1862 \\
\hline Sobieskiplatz & 1862 \\
\hline Zamenhofgasse & 6.6 .1956$, komisja rady gminnej \\
\hline
\end{tabular}


Okres, w którym nadawano nazwy ulic, jest zapewne związany z ważniejszymi prądami umysłowymi, kulturowymi czy społecznymi danej epoki. Najwcześniej, bo jeszcze za życia polityka, nadano nazwę ulicy Possingera. Jest to fakt o tyle zaskakujący, że Possinger nie wydaje się być tak wybitną postacią na tle jemu współczesnych, by zasłużyć na to wyróżnienie. Niestety w wiedeńskim archiwum (Landes und Stadtsarchiv) nie były dostępne dokumenty z 1887 roku, które mogłyby wyjaśnić to zdarzenie. Pod względem politycznym Polacy odgrywali w tym czasie w Monarchii znaczącą rolę, mówiono wręcz ironicznie o "polskich rządach w Austrii” ${ }^{6}$ i tym faktem prawdopodobnie należy tłumaczyć uczczenie jednego z polskich polityków nazwą ulicy. Krótko po śmierci, bo zaledwie po 5 latach, został uhonorowany swą ulicą architekt Borkowski. Uliczka Borkowskiego znajduje się w pobliżu osiedla, które projektował. Z tego powodu zapewne otrzymała ona jego imię (Stadtratsitzung, 24 II 1910). Tego dnia nie były nadawane inne nazwy, tym bardziej więc należy sądzić, że chodziło o uczczenie zasług naszego architekta. Po 8-miu latach po śmierci zostali uczczeni Luxemburg i Huberman. Róża Luxemburg7 nigdy w Wiedniu na była. Popularność tej postaci należy tłumaczyć ówczesnymi lewicowymi rządami w stolicy ${ }^{8}$ - tego samego dnia nadano również następujące nazwy ulic upamiętniające osoby o podobnej orientacji politycznej: Liebknechtgasse ${ }^{9}$, Matteottiplat ${ }^{10}$ i Nietscheplatz (Ausschuss für technische Angelegenheiten, 5 I 1927). Ponowne nadanie nazwy ulicy Luxemburg w 1947 r. było zapewne związane z powojenną tendencją do denazyfika$\mathrm{cji}^{11} \mathrm{i}$ chęcią powrotu do przedwojennych tradycji ${ }^{12}$. Natomiast nazwy ulic

${ }^{6}$ Por. Die Polen im Österreichischen Parlament, Lublin/Wien 1997, s. 9 i dalej; M. Seliger / K. Ucakar, Wien - politische Geschichte 1740 -1934, Wien / München, 1985, s. 357 i dalej.

7 Ulica Luxemburg istniała w latach 1927-34, następnie ponownie od roku 1947.

8 12.11.1918 powstała Niemiecko-Austriacka Republika z rządem socjalistycznym pod przewodnictwem socjalisty kanclerza Karla Rennera. Na mocy konstytucji z 1920 roku Wiedeń otrzymał prawo samodzielnego landu i stał się twierdzą socjalistów austriackich. Rządy socjalistów trwały aż do początku władzy faszystów, którzy usunęli socjalistów w latach 1933-34. Po roku 1934 nastąpiła walka zbrojna pomiędzy socjalistami i faszystami, w której pierwsi przegrali a drudzy odnieśli sukces. Por. H. Wereszycki, Historia Austrii, Wrocław / Warszawa / Kraków 1996, s. 286 i dalej.

9 Socjaldemokratyczny poseł niemiecki, padł ofiarą swoich przekonań podczas berlińskiego powstania styczniowego (razem z Różą Luxemburg).

10 Sekretarz włoskiej socjalistcznej partii, poseł, równiez padł ofiarą swoich zapatrywań.

11 Por. E. Hanisch, Österreichische Geschichte 1890-1955, Wien 1994, s. 475.

${ }^{12}$ W roku 1945 nastąpiło odnowienie partii socjalistycznej SPÖ przez Karla Rennera. Renner został mianowany kanclerzem nowego rządu. Następnie, w tym samym roku, powstał rząd koalicji ÖVP i SPÖ, którego kanclerzem został L. Figl z ÖVP, a wicekanclerzem- 
Hubermana i Godowskiego zostały nadane w dniu, gdy nadawano nazwy upamiętniające innych muzyków ${ }^{13}$ (Gemeinderatausschuss III, 7 XII 1955). Ponadto $\mathrm{w}$ jesieni tego samego roku miała miejsce podniosła uroczystość otwarcia po odbudowie powojennej dwóch najważniejszych wiedeńskich oper. Duży rozgłos został nadany szczególnie otwarciu opery państwowej (Staatsoper) w dniu 5-ego listopada ${ }^{14}$. Na nadanie nazwy ulicy Kiepury - w roku 1975, już 9 lat po śmierci artysty - ewentualnie mogła też mieć wpływ pierwsza po wojnie oficjalna wizyta polskiego premiera P. Jaroszewicza w Austrii. Była ona związana z ponownym nawiązaniem stosunków międzynarodowych pomiędzy Polską a Austrią ${ }^{15}$. Tego samego dnia uczczono również inną postać związane z kulturą: pisarza F. Ichmanna, ponadto 9 czerwca 1975 r. nadano jednej z ulic nazwę F. T. Csokora - poety i dramaturga związanego z Polską (GRA III, 12 V 1975). Z grona naukowców najszybciej doczekał się swej pamiątki w postaci ulicy Zamenhof -już w 12 lat po śmierci (Ausschuss für allgemeine Verwaltung, 17 VII 1929). Fakt ten należy łączyć z wzrastającą popularnością międzynarodowego języka esperanto w kraju, który przez wiele stuleci był monarchią łączącą wiele narodów i kultur ${ }^{16}$. Ulicą Leszetyckiego uhonorowano muzyka w 1932 r., 17 lat po jego śmierci. Po I wojnie światowej znów ożyły wiedeńskie tradycje muzyczne ${ }^{17}$. W dniu uhonorowania Leszetyckiego nadano kilku ulicom imiona innych artystów: malarza barokowego F.Ch. Janecka, malarzy kwiatów J. Schustera i F. X. Bettera, malarza pejzaży G. Jettela jak również poety Gutzowa (Gemeinderatsausschuss III, 3 X 1932). Czartoryski został patronem ulicy jeszcze w XIX wieku, w roku 1894, 34 po śmierci. Na ten okres datuje się coraz większy wzrost znaczenia i wpływów Polaków w rządzie Austro-Węgier ${ }^{18}$. W tym samym dniu uczczono w podobny sposób pamięć innego, wybitniejszego człowieka kultury - Schumanna.

Rittner został upamiętniony swą ulicą w 1960 r., 39 lat po śmierci. Tego samego dnia nadano nazwy ulicom w celu uczczenia kilku innych postaci związanych również z kulturą. Byli to: pisarze H. B. Bornstein

socjalista A. Schärf. Por. H. Wereszycki, Historia Austrii, Wrocław / Warszawa / Kraków 1996; M. Seliger / K. Ucakar, Wien - politische Geschichte 1740 -1934, Wien / München, 1985, s. 357 i dalej.

${ }^{13}$ Również tego samego dnia uczczono ulicami postaci znaczącego dyrygenta F.O. Dessoffa, dyrygenta i kompozytora F. Drdla oraz śpiewaczki operowej R. P. Papier.

14 Por. Amtsblatt der Stadt Wien, 1955, nr 61.

15 Por. W. Kleindel, Österreich - Daten zur Geschichte und Kultur, Wien 1978, s. 452.

16 Por. Esperanto-Ereignisse in Österreich. Seite Österreichischer Esperanto-Bewegung, http: //www. 8ung. at/esperanto-aem/espinoe. htm.

17 Por. F. M. Mayer / R. Kaindl / H. Pirchegger, Geschichte und Kulturleben Österreichs, Wien 1965, s. 411.

18 Por. też Abschied von Czartoryski-Schlössel, [w:] "Amtsblatt der Stadt Wien“, 1955, nr 100. 
i H. B. Bergler oraz wydawca J. A. L. Staackmann (Gemeinderatausschuss III, 28 IX 1960). W 39 lat po śmierci nadano nazwę ulicy Curie. W tym samym dniu swych ulic doczekali się też inni znaczący fizycy: noblista profesor doktor E. Schrödiger, profesor doktor Josef Herzig i profesor doktor A. Lampa oraz zmarła 5 lat wcześniej austriacka fizyczka profesor doktor L. Meitner (Gemeinderatausschuss III, 23 I 1973). Nadanie nazwy ulicy upamiętniającej Alberta (1862 r.) łączy się zapewne z ówczesnymi żywymi tradycjami kulturalnymi. Wiedeń drugiej połowy XIX wieku przeżywał czas swej wyjątkowej świetności i rozkwitu jako jedno z europejskich centrów kultury. Natomiast przedłużenie ulicy w 1905 r. nastąpiło z okazji 100. rocznicy powstania Wodociagu Albertyńskiego (Albertinische Wasserleitung $)^{19}$. Ponadto rok wcześniej powstał plac im. Alberta. Nazwano tak miejsce znajdujące się $\mathrm{w}$ obrębie ulicy Alberta - stąd prawdopodobnie idea nadania takiego właśnie imienia. W 50 lat po śmierci patrona nadano nazwę ulicy Gumplowicza. W tym samym dniu patronem ulicy został również inny prawnik, profesor Uniwersytetu Wiedeńskiego G. D. Demelius (Gemeinderatausschuss III, vom 15.April 1959). Nazwiskami Lipinera i Rittnera nazwano ulice na początku lat 60 . Lipiner został uhonorowany swą ulicą w tym samym dniu co inna przedstawicielka artystów, śpiewaczka operowa Maria Gutheil-Schoder. Podobnie odbyło się w przypadku Rittnera - w tym samym dniu zostali wyróżnieni inni przedstawiciele świata kultury - pisarze: H. B. Börnstein, H. B. Bergler, E. C. von Geldern i C. C. Corti, wydawca J. A. Staackman, poeata J. A. Gleich oraz publicysta J. A. von Pilat. Sobieski został uhonorowany w przeddzień 200. rocznicy odsieczy, w 1862 r. Według gazety Postęp miał to być tani sposób na uczczenie pamięci $\mathrm{króla}^{20}$. Podobną genezę ma nadanie nazwy ulicy Kulczyckiego w tymże samym roku. Natomiast nazwę ulicy Kopernika nadano aż 324 lata po śmierci astronoma, w $1867 \mathrm{r}$. Wydarzenie to miało miejsce w II połowie XIX wieku, gdy Wiedeń stał się m.in. jednym z centrów życia naukowego Europy. Fakt ten sprzyjał uczczeniu pamięci właśnie naukowców.

\subsection{Lokalizacja ulic}

W najstarszej części miasta Innere Stadt (dzielnica 1) nie ma w ogóle polskich ulic. Natomiast na bliższych przedmieściach (dzielnice 3-9) znajduje się ich sześć: są to ulice Kulczyckiego, Kopernika, Alberta, Sobieskiego, plac Alberta oraz plac Sobieskiego. Są to nazwy nadane najwcześniej: w latach 1862 (Albert, Sobieski, Kulczycki) i 1867 (Kopernik). Z końca

19 Por. F. Czeike, Historisches Lexikon Wien, Tom 1, Wien 1994, s. 38.

20 Por. „Postęp”, 1962, nr 28. 
XIX-tego wieku pochodzą jeszcze jedynie dwie nazwy (ulica Possingera z 1887 r. w dzielnicach 15-16 oraz ulica Czartoryskiego z 1894 r. w dzielnicach 17-18), natomiast z początku XX wieku - plac Alberta (1904). Wszystkie pozostałe "polskie” ulice znajdują się na dalszych przedmieściach (dzielnice 10-23) i pochodzą z XX wieku. Najwięcej „polskich” ulic - 3 - znajduje się w nowszych dzielnicach: o numerze 22 (ulice Curie, Rittnera i Gumplowicza) oraz 23 (ulice Godowskiego, Hubermana i Lipinera). Dwie nazwy upamiętniające Polaków znajdują się w dzielnicy 18 (ulice Czartoryskiego i Leszetyckiego). Kolejne dwie polskie nazwy znajdują się w dzielnicy 9 (ulica i plac Sobieskiego) jak również w dzielnicy 16 (ulice Possingera i Luxemburg). Po jednej polskiej nazwie jest tez $\mathrm{w}$ dzielnicach 11 i 14 (Kiepura, Zamenhof).

W przypadku 8-miu nazw ulic celem było zapewne uczczenie właśnie w tym miejscu pamięci zasłużonych Polaków: ulica i plac Sobieskiego to droga, którą uroczyście wjeżdżał do miasta polski król po odsieczy wiedeńskiej, entuzjastycznie witany przez mieszkańców miasta ${ }^{21}$. Nazwy zostały nadane z okazji zbliżającej się 200. rocznicy odsieczy. Ulica Kulczyckiego łączy się z ulicą Grafa Starhemberga (Graf-StarhembergGasse ${ }^{22}$. Ulica Borkowskiego znajduje się na pograniczu dzielnic, których willowe osiedla budował ten polski architekt (Währing i Döbling) ${ }^{23}$. Natomiast ulica Leszetyckiego przebiega w tej samej dzielnicy, w której mieszkał sławny muzyk. Nie prowadzi jednak dokładnie koło jego domu zamieszkania - na domu znajduje się natomiast pamiątkowa tablica. Ulica Czartoryskiego została wytyczona niedaleko miejsca, gdzie do roku 1957 znajdował się pałac Czartoryskich. Nie jest to jednak dokładnie ta droga, przy której stał wspomniany budynek, a jedynie jej pobliże. Lokalizacja ulicy i placu Alberta jest związana z ufundowanym przez niego Wodociagu Albertyńskiego (Albertinische Wasserleitung). Wodociąg zaopatrywał $\mathrm{w}$ wodę zdatną do picia dzielnice $6-8^{24}$.

Natomiast lokalizacja 11 pozostałych ulic wydaje się nie wykazywać szczególnego związku z działalnością ich patronów. Trzy spośród uczczonych osób (Curie, Luxemburg i Kopernik) w ogóle w Wiedniu nie mieszkały, ulice w dzielnicach 22 i 23, upamiętniające Godowskiego, Gumplowicza, Hubermana, Lipinera i Rittnera, były wytyczane w wiele lat po śmierci ich patronów. Dotyczy to również ulicy Kiepury w 14. dzielnicy.

Spośród 19 „polskich” nazw wiedeńskich ulic, 12 to nazwy nowo nadane (ulice Borkowskiego, Curie, Kiepury, Kopernika, Leszetyckiego,

\footnotetext{
21 Por. „Postęp", 1962, nr 28.

22 Graf Starhemberg był dowódcą obrony Wiednia w 1683 r.

${ }^{23}$ Por. R. Wagner-Rieger, Wiens Architektur im XIX. Jahrhundert, Wien 1970, s. 216.

24 Por. R. Groner / F. Czeike, Wien wie es war, Wien / München 1957, s. 14.
} 
Lipinera, Luxemburg, Possingera, Rittnera, Zamenhofa ${ }^{25}$, Gumplowicza i plac Alberta), natomiast $7 \mathrm{z}$ nich to ulice noszące wcześniej inną nazwę (ulice Alberta, Czartoryskiego, Godowskiego, Hubermana, Kulczyckiego, Sobieskiego i plac Sobieskiego). Wydaje się, że większym uhonorowaniem patrona wydaje się być zmiana nazwy ulicy na jego szczególną cześć, niż nadanie nazwy nowo powstałej drodze. Uzasadnieniem zamiany były rocznice ważnych wydarzeń (w przypadku Sobieskiego - zbliżająca się rocznica odsieczy, natomiast $\mathrm{w}$ odniesieniu do Alberta - 100. rocznica ufundowania przez niego wodociągu), ówczesny klimat kulturowy (Godowski, Huberman) czy wzrost znaczenia Polaków w ówczesnych warunkach polityczno - kulturalnych (Czartoryski). Nie miał natomiast miejsca fakt, by zmieniono patrona ulicy nazwanej uprzednio na cześć Polaka.

\section{Obecność innych znanych Polaków w Wiedniu $\mathrm{w}$ analogicznym okresie}

Oczywiście wybór tych a nie innych postaci na patronów ulic jest nacechowane pewną dozą subiektywizmu ze strony osób proponujących nadanie nazwy. W Wiedniu przebywało wszak także, choćby na przełomie XIX-tego i XX-tego wieku, wiele innych znakomitości reprezentujących m.in. kulturę i politykę, spośród których warto wymienić przynajmniej - z uwagi na szczupłość miejsca - następujące osoby ${ }^{26}$ :

\subsection{Osobistości świata kultury}

\subsubsection{Pisarze}

Józef Ignacy Kraszewski, 1812-1887. W maju 1858 r. przebywał około jednego tygodnia w Wiedniu - pobyt ten opisał dokładnie w swoich Kartkach z podróży; w 1879 r. brał udział w audiencji u cesarza, dziękując za odznaczenie Krzyżem Komandorskim Orderu Franciszka Józefa; uczestniczył także w wiedeńskim IV. Kongresie Międzynarodowego Towarzystwa Literackiego w 1881 r.; w latach 1880-1881 w Wiedniu wydano w języku niemieckim 10-cio tomowe dzieła Kraszewskiego. Ponadto kilka powie-

${ }^{25}$ Ulica Zamenhofa to nazwa dwukrotnie nowo nadana. W dzielnicy 12 ulica Zamenhofa była w latach 1929-55, obecnie od 1956 r. znajduje się ona w dzielnicy 11. Por. F. Czeike, Historisches Lexikon Wien, Tom 5, Wien 1997, s. 686.

${ }^{26}$ Lista przytoczona jest w porządku chronologicznym, według klucza roku urodzenia postaci. 
ści tego autora było drukowanych w wiedeńskich czasopismach ${ }^{27}$. Maria Konopnicka, 1842-1910. W latach 80. i 90. XIX-tego wieku przebywała na letnich kuracjach w Alpach Austriackich ${ }^{28}$; po drodze na leczenie zatrzymywała się także m.in. w Wiedniu ${ }^{29}$. Prus Boleslaw, 1847-1912. W 1881 r. uczestniczył w IV Kongresie Międzynarodowego Towarzystwa Literackiego w Wiedniu ${ }^{30}$. Gabriela Zapolska, 1857-1921. W 1881 r. przybyła do Wiednia, by urodzić tam nieślubne dziecko Mariana Gawalewicza. Córka wkrótce zmarła. Podczas I wojny światowej dużą popularnością cieszyły się w Wiedniu jej antyrosyjskie sztuki Tamten i Sybir. Sztuka Tamten, pod tytułem Die Warschauer Zitadelle, utrzymywała się przez okres 2 lat (1916-1918) w repertuarze teatru Kammerspiele. Wystawiano ją około 300 razy $^{31}$. Zenon Przesmycki, 1861-1944. W latach 1890-1893 mieszkał w Wiedniu, gdzie studiował prawo; był aktywnym członkiem Towarzystwa Biblioteki Polskiej w Wiedniu ${ }^{32}$. Stefan Żeromski, 1864-1925. W styczniu 1892 r. oraz w listopadzie 1906 r., będąc w drodze do Szwajcarii, zatrzymał się w Wiedniu. Swe wspomnienia z metropolii Habsburgów zawarł w drugim tomie Dziejów grzechu - to właśnie w stolicy Austrii rozgrywają się duże fragmenty tego utworu ${ }^{33}$. Stanisław Przybyszewski, 1868-1927. Po przeniesieniu się do Monachium w 1906 r. bywał częstym gościem w Wiedniu, gdzie pojawiał się z odczytami. Był już wtedy znany wiedeńskiej publiczności, ponieważ w latach 90. XIX-tego wieku teksty tego autora były publikowane w znanym wiedeńskim tygodniku Die Zeit. Recenzje twórczości Przybyszewskiego zamieszczano także w czasopismach Wiener Rundschau i Wiener Abendpost. Jeden z wiedeńskich teatrów wystawiał jego sztuki Das große Glück, Die Mutter i Das goldene Vlies. Po wybuchu I wojny światowej Przybyszewski współpracował z Wiedeńskim Kurierem Polskim. W 1915 r. polonia wiedeńska zorganizowała dla niego święto jubileuszowe z okazji 25-cio lecia działalności twórczej ${ }^{34}$. Zofia Nałkowska, 1884-1954. W 1931 r., w drodze do Jugosławii i Grecji, zwiedziła Wiedeń. Szczególna uwagę zwróciła na nowe osiedla robotnicze - motyw

27 Por. W. Danek, Józef Ignacy Kraszewski, [w:] PSB, tom 15, Wrocław 1970, s. 221-229.

${ }^{28} \mathrm{Na}$ budynku, gdzie mieszkała ona $\mathrm{w}$ Ischl, znajduje się tablica pamiątkowa, odsłonięta w 1972 r. staraniem Towarzytwa Austriacko-Polskiego. Por. R. Taborski, Polacy w Wiedniu, Wrocław 1992, s. 112.

${ }_{29}$ Por. J. Baculewski, Maria Konopnicka, [w:] PSB, tom 13, Wrocław 1967-1968, S. 576-581.

30 Por. R. Taborski, Polacy w Wiedniu, Wrocław 1992, s. 107-108.

31 Por. J. Czachowska, Gabriela Zapolska: monografia bio-bibliograficzna, Kraków 1966, s. 200, 224, 487, 492.

32 Por. B. Koc, Zenon Przesmycki, [w:] PSB, tom 29, Wrocław 1986, s. 15-20.

33 Por. Żeromski. Kalendarz życia i twórczości, 1976, s. 118.

${ }^{34}$ Ibidem, s. 117 i dalej 
ten wprowadziła następnie do powieści Granica ${ }^{35}$. Jaroslaw Iwaszkiewicz, 1894-1980. W 1926 r. uczestniczył w wiedeńskim kongresie Unii Intelektualnej $^{36}$. Józef Wittlin, 1896-1976. W 1914 r. zdał w Wiedniu maturę. Następnie studiował filozofię na Uniwersytecie Wiedeńskim. Od 1916 r. był ochotnikiem w wojsku austriackim ${ }^{37}$.

\subsubsection{Muzycy}

Marcelina Sembrich-Kochańska, 1858-1935. W 1874 r. przybyła do Wiednia, by kształcić się tam w śpiewie i grze na fortepianie. W $1877 \mathrm{r}$. wystąpiła $\mathrm{z}$ sukcesem $\mathrm{w}$ operze wiedeńskiej - podziwiał ja wtedy m.in. sam następca tronu Rudolf. W tym samym roku opuściła Wiedeń, udając się do Włoch ${ }^{38}$. Ignacy Jan Paderewski, 1860-1941. W latach 1884-1885 w Wiedniu pobierał nauki u Teodora Leszetyckiego. Mieszkał wtedy nieopodal domu nauczyciela w dzielnicy Währing; w latach 1887/1888 brał udział w kilku wiedeńkich koncertach ${ }^{39}$. 24. 01. 1889 koncertował na fortepianie w Bösendorfersaal; z kolei w 1901 r. - występował w sali Musikvereinsgebäude ${ }^{40}$. Grzegorz Fitelberg, 1879-1953. W latach 1911/12 oraz 1912/13, razem z K. Szymanowski, przebywał w Wiedniu. W okresie od marca 1912 r. do końca 1913 r. był jednym z dyrygentów Opery Wiedeńskiej ${ }^{41}$. Ada Sari, 1886-1968. W Wiedniu przebywała w latach 1905-1907, ucząc się tam w Prywatnej Szkole Muzycznej. W 1907 r. po raz pierwszy wystąpiła publicznie w stolicy Austrii. Jej śpiew zebrał pozytywne recenzje prasowe. W Wiedniu zatrzymała się również w latach 1914-1915, gdy - jako obywatelka Austrii - po wybuchu I wojny światowej była zmuszona opuścić Włochy ${ }^{42}$. Artur Rubinstein, 1887-1982. W 1910 r. wystąpił w sali Musikvereinsgebäude z trzema koncertami fortepianowymi, następnie koncertował w Bösendorfersaal. W stolicy Austrii występował także w latach 1912, 1913 i $1914^{43}$.

35 Por. R. Taborski, Polacy w Wiedniu, Wrocław 1992, s. 187-188.

36 Por. J. Czachowska, Współcześni polscy pisarze i badacze literatury, tom 3, Kraków 1994, s. 317-319.

37 Por. Słownik Pisarzy Polskich, Warszawa 2003, s. 534.

38 Por. J. Grubowski, Marcelina Sembrich-Kochańska, [w:] PSB, tom 13, Wrocław 1967-1968:203-205.

39 Por. M. Perkowska/R. Wapiński, Ignacy Paderewski, [w:] PSB, tom 24, Wrocław 1979, s. 795-803.

40 Por. R. Taborski, Polacy w Wiedniu, Wrocław 1992, s. 147-148.

41 Por. SMP, t. 1, Kraków 1964, s. 140-141.

42 Por. M. Komorowska, Ada Sari, [w:] PSB, tom 35, Wrocław1994, s. 194-197.

43 Por. A. Rubinstein, Moje młode lata, Kraków 1976, s. 356-363, 434-439, 463-465, 488. 


\subsubsection{Malarze}

Henryk Rodakowski, 1823-1894. Absolwent wiedeńskiego Theresianum, które ukończył w 1841 r. W stolicy Austrii studiował malarstwo, ukończył tam także prawo w 1845 r. Do Wiednia powrócił ponownie na lata 1889-189344. Jan Matejko, 1838-1893. Od 1860 r. studiował malarstwo w Wiedniu. W 1867 r. cesarz Franciszek Józef zakupił jego obraz Rejtan. W 1869 r. Matejko wystawiał w Wiedniu swą Unię Lubelska, a w 1872 r. - Batorego pod Pskowem. W 1873 r., podczas światowej wystawy w Wiedniu, była licznie reprezentowana działalność artystyczna Matejki. W 1882 r. spędził w stolicy Austrii około tygodnia, pracując nad obrazem Jan Sobieski pod Wiedniem - dzieło zostało zaprezentowane przy okazji uroczystości związanych z 200. rocznicą odsieczy (1883 r.) w GartenbauGesellschaft przy Parkring 12. W 1888 r. Matejko uczestniczył audiencji u cesarza, składając podziękowania za otrzymany medal Litteris et artibus, będący najwyższym austriackim odznaczeniem za zasługi $\mathrm{w}$ dziedzinie sztuki i nauki ${ }^{45}$. Tadeusz Ajdukiewicz, 1852-1916. W Wiedniu przebywał od około 1880 r. do początku lat 90. XIX. stulecia. Portretował m.in. cesarza Franciszka Józefa, arcyksięcia Rudolfa i inne znaczące osobistości z kręgów dworskich ${ }^{46}$. Kazimierz Pochwalski, 1855-1940. Uprawiał także malarstwo religijne i rodzajowe, pozostawił liczne szkice pejzażów, kwiatów i martwych natur. W 1879 r. studiował w Wiedniu malarstwo, ponadto w latach 1893-1918 mieszkał w stolicy Habsburgów, gdzie był profesorem Akademii Sztuk Pięknych (Akademie der bildenden Künste). Portretował cesarza, członków rodziny cesarskiej, arystokratów i polityków. W $1891 \mathrm{r}$. za swe portrety został uhonorowany złotym medalem na międzynarodowej wystawie w Künstlerhaus. Był jednym z współzałożycieli wiedeńskiej secesji ${ }^{47}$. Wojciech Kossak, 1856-1942. Od 1882 r. wystawiał swe prace w Künstlerhaus. Często uczestniczył w cesarskich polowaniach i paradach. W latach 1904-1905 mieszkał w stolicy Austrii, gdzie pracował w atelier przy Schwarzenbergplatz. Portretował cesarza i inne znane osobistości miasta. W 1908 r., z okazji 60-lecia panowania cesarza Franciszka Józefa I, uczestniczył w uroczystym pochodzie, wcielając się $\mathrm{w}$ rolę samego Jana III Sobieskiego ${ }^{48}$. Zygmunt Ajdukiewicz, 1861-1917. W latach 1880-1882 studiował w Wiedniu. Od 1885 r. osiadł w tym mieście na stałe, był popularnym portrecistą osób z kręgów dworskich, arystokratycznych

${ }^{44}$ Por. A. Ryszkiewicz, Henryk Rodakowski, [w:] PSB, tom 31, Wrocław 1988-89, s. 341-347.

45 Por. R. Taborski, Polacy w Wiedniu, Wrocław 1992, s. 129-131.

46 Por. L. Lepszy, Tadeusz Ajdukiewicz, [w:] PSB, tom 1, Kraków 1935, s. 35-36.

47 Por. R. Biernacka, Kazimierz Pochwalski, [w:] PSB, tom 27, Wrocław 1983, s. 13-16.

48 Por. I. Trybowski, Wojciech Kossak, [w:] PSB, tom 14, Wrocław 1968, s. 248-251. 
i ministerialnych. W 1891 r. został odnaczony złotym medalem na wystawie w Künstlerhaus ${ }^{49}$. Bolesław Czedekowski, 1885-1969. W Wiedniu od 1903 r. ${ }^{50}$ Po ukończeniu Akademii Sztuk Pięknych (Akademie der bildenden Künste) praktykował u Kazimierza Pochwalskiego. W 1909 r. został odznaczony za zasługi w dziedzinie malarstwa olejnego. Podczas I wojny światowej był portrecistą wojskowym. Po zakończeniu działań wojennych mieszkał w USA, Paryżu, Warszawie. W 1939 r. zdecydował się na stały pobyt w Wiedniu, gdzie osiadł już do końca życia, z przerwą na powrót do USA w latach 1945-1953. Angażował się w działalność Związku Polaków w Austrii Strzecha oraz Towarzystwa Austriacko-Polskiego. W 1964 r. w wiedeńkim pałacu Palffy mała miejsce znacząca wystawa jego prac, która przyciągnęła dużą uwagę intelektualistów i krytyków.

\subsubsection{Inni}

Karol Lanckoroński, 1848-1933, mecenas sztuki, kolekcjoner, tajny radca, dziedziczny członek Izby Panów, szambelan, Wielki Ochmistrz dworu cesarskiego, kawaler Orderu Złotego Runa, urodzony w Wiedniu, gdzie spędził całe swe życie ${ }^{51}$. Marian Smoluchowski, 1872-1917, fizyk, profesor Uniwersytetu Lwowskiego i Jagiellońskiego, jeden z najgenialniejszych badaczy w historii nauki polskiej. Sam A. Einstein wykorzystał jego prace $w$ celu sformułowania teorii wyjaśniającej chaotyczne ruchy cząstek. Smoluchowski pracował pewien okres czasu na Uniwersytecie Wiedeńskim na stanowisku docenta ${ }^{52}$.

\subsection{Osobistości świata polityki}

Kazimierz Grocholski, 1815-88, polityk galicyjski, jeden z czołowych członków ugrupowania „Podolacy“; od 1861 r. poseł do Sejmu Krajowego Galicji, poseł w austriackim parlamencie, w latach 1868-1888 prezes Koła Polskiego w parlamencie austriackim, od 1871 r. pierwszy minister do spraw Galicji w rządzie Austrii. W sejmie przewodniczył pracom znaczących komisji: administracyjnej, gminnej, adresowej; przyczynił się do wypracowania wielu ustaw, m.in. gminnej, szkolnej, drogowej i myśliwskiej ${ }^{53}$. Alfred Potocki, hrabia, 1822-1889, galicyjski ziemianin, polityk;

\footnotetext{
49 Por. M. Treter, Zygmunt Ajdukiewicz, [w:] PSB, tom 1, Kraków 1935, s. 36.

50 Por. K. Strobl, B. J. Czedekowski, Wien 1960, s. 23.

51 Por. R. Taborski, Polacy w Wiedniu, Wrocław 1992, s. 442-443.

52 Por. J. Buszko, Od niewoli do niepodległości, Kraków 2000, s. 137, 140 i dalej.

53 Por. S. Kieniewicz, Kazimierz Grocholski, [w:] PSB, tom 8, Wrocław 1959-1960, s. $585-587$.
} 
od 1861 r. poseł do Sejmu Krajowego Galicji, szambelan austriacki, odznaczony przez cesarza Franciszka Józefa Orderem Złotego Runa; w latach 1875-1877 marszałek krajowy, 1867-1870 austriacki minister rolnictwa, w 1870 r. premier Austrii, w latach 1875-1883 namiestnik Galicji; liberalny konserwatysta i monarchista; współorganizator przemysłu w Galicji i na Ukrainie $^{54}$. Julian Dunajewski ${ }_{\llcorner}$1824-1907, konserwatywny polityk galicyjski, profesor Uniwersytetu Jagiellońskiego, członek Polskiej Akademii Umiejętności, poseł do Sejmu Krajowego Galicji (1864-1907) oraz poseł parlamentu austriackiego (1873-1889), austriacki minister skarbu (18801891). Przeprowadził na tym stanowisku reformę systemu podatkowego - za pomocą bardziej elastycznego opodatkowania udało mu się zrównoważyć budżet, wprowadził m.in. podatki pośrednie oraz podwyższył cła od kawy oraz podniósł ceny wyrobów tytoniowych ${ }^{55}$. Kazimierz Badeni, hrabia, 1846-1909, konserwatywny polityk galicyjski, w latach 18881895 namiestnik Galicji, 1895-1897 premier Austrii. Jego rząd upadł pod wpływem oporu Niemców i socjalistów po tym, gdy wprowadził w Czechach równouprawnienie języków czeskiego i niemieckiego ${ }^{56}$. Leon Biliński, 1846-1923, konserwatywny polityk galicyjski, ekonomista, profesor i rektor Uniwersytetu Lwowskiego; przez okres 25-ciu lat był członkiem rządu austriackiego i pełnił szereg funkcji w administracji austro-węgierskiej, będąc posłem parlamentu w Wiedniu, wiceprezesem (1897-1900) i prezesem (1911-1912, 1915-1918) Koła Polskiego w austriackiej Radzie Państwa; w latach 1893-1895 był prezydentem C.K. Austriackich Kolei Państwowych (Kaiserlich-königliche österreichische Staatsbahnen), 1895-1897 ministrem skarbu Austrii, 1900-1909 gubernatorem Banku Austro-Węgierskiego (Österreichische-Ungarische Bank), 1909-1910 ponownie ministrem skarbu Austrii, 1912-1915 wspólnym ministrem skarbu Austro-Węgier i namiestnikiem cywilnym Bośni i Hercegowiny. Intensywnie działał na rzecz nawiązania polsko-austriackich stosunków ekonomicznych, będąc m.in. prezydentem nowo utworzonego w Wiedniu Banku Polsko-Austriackiego (Polnische-Österreichische Bank) ${ }^{57}$. Agenor Gołuchowski (syn), hrabia, 1849-1921, polityk i dyplomata; w austriackiej służbie dyplomatycznej od 1872 r.: w 1872 r. - attaché w ambasadzie austriackiej w Berlinie; w latach 1883-1887 - w Paryżu jako radca legacyjny w ambasadzie austriackiej; w latach 1887-1894 - ambasador w Rumunii; 1895-1906 - minister spraw zagranicznych Austro-Węgier ${ }^{58}$. Józef Piłsudski, 1867-1935,

\footnotetext{
${ }_{54}$ Por. J. Zdrada, Alfred Potocki, [w:] PSB, tom 27, Wrocław 1983, s. 762-766.

55 Por. S. Głąbiński, Leon Biliński, [w:] PSB, tom 2, Kraków 1936, s. 97-98.

56 Por. S. Starzyński, Kazimierz Badeni, [w:] PSB, tom 1, Kraków 1935, s. 205-207.

57 Por. S. Głąbiński, Leon Biliński, [w:] PSB, tom 2, Kraków 1935, s. 97-98.

58 Por. J. Buszko, Agenor Gołuchowski, [w:] PSB, tom 8, Wrocław 1959-1960, s. 260-
} 
polityk, działacz niepodległościowy Naczelnik Państwa w latach 19181922, pierwszy marszałek Polski od 19 marca 1920; dwukrotny premier Polski (1926-1928 i 1930). Przebywał w Wiedniu w dniach 18-22 grudnia 1914 r. Jego celem było przeprowadzenie rozmów z kierownictwem NKN. Został entuzjastycznie powitany przez Polaków na Dworcu Wschodnim. Mieszkał w hotelu Regina na rogu Währigerstraße i Votivplatz ${ }^{59}$.

Warto w tym miejscu wspomnieć o pozostałych ministrach - Polakach w rządzie Austro-Węgier. Byli to także, poza osobistościami wymienionymi powyżej: Agenor Gołuchowski (ojciec) - minister spraw wewnętrznych w latach 1859-1860, minister stanu w 1860 r.; Stanisław Madeyski - minister wyznań i oświaty w latach 1893-1895; Edward Rittner - kierownik Ministerstwa Wyznań i Oświaty w 1895 r.; Seweryn Kniaziołucki - kierownik Ministerstwa Finansów w 1899 r.; Witold Korytowski - minister finansów w latach 1906-1908; Stanisław Głąbiński - minister kolei w 1911 r.; Wacław Zaleski - kierownik Ministerstwa Rolnictwa w 1911 r., minister finansów w latach 1911-1913; Ludwik Ćwikliński - minister wyznań i oświaty w latach 1917-1918; Jerzy Madeyski - minister wyznań i oświaty w $1918 \mathrm{r}$.

\section{Uwagi końcowe}

Wiedeń od wielu stuleci fascynował Polaków. Nasi rodacy ściągali tłumnie do stolicy Monarchii Naddunajskiej. Proces ten szczególnie przybrał na sile w czasie, gdy Galicja stała się częścią Austro-Węgier, aż do wybuchu I wojny światowej. Złożyło się na to wiele czynników, m.in. rozkwit szeroko pojętego życia umysłowego Wiednia tej epoki, udział Polaków w centralnych władzach Monarchii, łatwość dotarcia do stolicy ${ }^{60}$ czy chęć ucieczki od przysłowiowej nędzy galicyjskiej ${ }^{61}$.

Na podstawie danych ilościowych przytoczonych powyżej można pokusić się o próbę podsumowania recepcji relacji polsko-austriackich z perspektywy "polskich” ulic w Wiedniu. W gronie wybitnych Polaków, których życie i działalność zostały docenione w tak dużym stopniu, że inny kraj niż ojczyzna uczcił ich pamięć nazwą ulicy, najwięcej jest przedstawicieli świata kultury (13). Przeważają w tym gronie muzycy (4). Fakt ten nie dziwi, ponieważ od stuleci nieodłącznym elementem

261.

59 Por. R. Taborski, Polacy w Wiedniu, Wrocław 1992, s. 169.

${ }^{60}$ Por. B. Kepnik, Związki komunikacyjne pomiędzy Polską a Austrią na przestrzeni wieków, [w:] Polacy w Austrii, pod red. A. Pilcha, Kraków 1976, s. 191 i dalej.

${ }_{61}$ Por. S. Szczepanowski, Nędza Galicyi w cyfrach, Lwów 1888, s. 26. 
czaru cesarskiego Wiednia była właśnie ta dziedzina sztuki. Szczególnie w drugiej połowie XIX-tego stulecia, aż do wybuchu I wojny światowej, w okresie politycznej stabilizacji i dynamicznego rozwoju gospodarczego, blask Wiednia przyciągał wiele sław na miarę Europy, które nadawały ton szeroko pojętemu życiu kulturalnemu metropolii. W związku z tym do stolicy Monarchii Naddunajskiej ściągali artyści muzycy z różnych części kraju i zza jego granic w celach nauki u wybitnych mistrzów i odbywania koncertów w tak prestiżowym miejscu. Przynajmniej od początku XIX wieku większość słynnych polskich wirtuozów (pianistów, skrzypków, wiolonczelistów) uznawało za zaszczyt koncertowanie w Wiedniu - metropolii muzyki europejskiej ${ }^{62}$. Ponadto jednym z powodów częstych wyjazdów polskich muzyków do tego miasta była także możliwość otrzymania finansowego wsparcia ze strony wielu polskich rodzin magnackich, przykładowo Lubomirskich, Czartoryskich czy Potockich, mających w Wiedniu swoje pałace i utrzymujących tam własne kapele muzyczne. Poza tym $\mathrm{w}$ mieście o tak wspaniałych tradycjach muzycznych można było znaleźć zatrudnienie w kapelach arystokracji lub dworu cesarskiego $^{63}$. Dla Polaków duże znaczenie miała również działalność pedagogiczna doskonałego nauczyciela gry na fortepianie Teodora Leszetyckiego - do niego właśnie na naukę udawali się najzdolniejsi, bardziej majętni polscy pianiści.

W gronie Polaków uczczonych ulicami w Wiedniu znalazło się też 4-ech naukowców. Fakt ten ma także swoje uzasadnienie historyczne. Mianowicie w dziedzinie kultury umysłowej, szczególnie ostatnie dziesięciolecia istnienia Monarchii Austro-Węgierskiej był okresem wybitnych osiągnięć. W związku z bardzo wysokim poziomem kształcenia na wiedeńskich wyższych uczelniach uczyło się tutaj wiele młodzieży również z polskich terenów przedzaborowych. Jednak Wiedeńczycy uczcili też polskich uczonych światowego formatu, którzy nigdy w Wiedniu nie byli.

Wiedeń, szczególnie w XIX-tym wieku aż do schyłku panowania dynastii Habsburgów, to również wymarzone miejsce dla mecenasów sztuki. Dla wielu polskich arystokratów w okresie, gdy Polska była pod zaborami, stolica Monarchii Naddunajskiej była wówczas miastem schronienia. Klimat artystyczny tego miasta, jak również moda na kolekcjonowanie sztuki była korzystna dla tego rodzaju działalności. Dla Polaków

62 Por. J. Forst-Battaglia, Polskie osiagnięcia kulturalne w Wiedniu", w: Austria-Polska. Z dziejów sąsiedztwa, pod red. W. Leitscha / M. Wawrykowej, Warszawa/Wien 1989, s. 238 i dalej; J. Forst-Battaglia, Polnisches Wien, Wien / München 1983, s. 80-86.

${ }_{63}$ Por. A. Nowak-Romanowicz, Związki z Wiedniem kompozytorów polskich drugiej połowy XVIII i pierwszej połowy XIX wieku, w: Polacy w Austrii, pod red. A. Pilcha, Kraków 1976, s. 97. 
istotnym był także jej aspekt patriotyczny - mianowicie chciano chronić przed rozproszeniem polskie dziedzictwo. Pamięć o niektórych mecenasach sztuki rodem z Polski podtrzymują trzy nazwy ulic. Jak już wspomniano powyżej, kontrowersyjną osobistością w tym gronie Polaków jest Albert Sasko-Cieszyński, syn polskiego króla.

Wiedeń był w drugiej połowie XIX-tego stulecia i na początku XX wie$\mathrm{ku}, \mathrm{z}$ uwagi na klimat intelektualny, jednym z najatrakcyjniejszych miast Europy. Od wieków uchodził także za atrakcję turystyczną. Z tych względów pewna grupa polskich m.in. pisarzy uczyniła to miasto celem swych podróży lub zwiedziała go w drodze do dalszych zagraniczych miejscowości - jak miało to miejsce w przypadku uczczonych tablicami pamiątkowymi S. Wyspiańskiego i H. Sienkiewicza. Natomiast pisarze polskiego pochodzenia, uczczeni w Wiedniu ulicą swego imienia to osoby, których losy zostały związane z Wiedniem już we wczesnej młodości: T. Rittner i Z. Lipiner spędzili większą część swego życia w Wiedniu, gdzie dali się poznać od najlepszej strony.

Z kolei politycy to grupa zawodowa Polaków, która w ostatnich dziesięcioleciach istnienia Monarchii, najmocniej zaznaczyła swą obecność w Wiedniu. Końcem XIX-tego wieku i na początku XX wieku jej przedstawiciele brali aktywny udział w centralnych władzach Austro-Węgier. Posługiwano się nawet określeniem „polskie rządy w Austrii”, lub - z większą dozą ironii - że Polacy po raz pierwszy od rozbiorów rządzą jakimś krajem ${ }^{64}$. Jednak historia potraktowała te osobistości nieszczególnie łaskawie - ich życie i działalność upamiętnia dziś jedynie ulica Possingera - osobistości bynajmniej nie najbardziej znanej z omawianej grupy postaci. Wiedeńczycy uczcili także znaną działaczkę ruchu rewolucyjnego Różę Luksemburg, która raczej nigdy nie odwiedziła tego miasta. Swą ulicę i plac posiada w Wiedniu także oczywiście król Jan III Sobieski. Jego ogromne zasługi podkreślają zgodnie nie tylko rodzimi historycy. Przykładowo w Wielkiej Historii Polski ${ }^{65}$ czyn Jana III został opisany w następujących słowach: Bitwa wiedeńska, która ocaliła Wiedeń od bliskiego już zdobycia go przez Turków, była największym do tego czasu zwycięstwem wojsk chrześcijańskich nad doborowa armiq muzutmańskiego najeźdźcy. [...] Została złamana ofensywna siła państwa ottomańskiego i odtąd miał się rozpoczać proces jego rozpadu. Natomiast znany na europejskim gruncie, teoretyk wojskowości pruski generał Carl von Clausewitz jeszcze niemal 200 lat po bitwie odsieczowej zaliczył Sobieskiego do najwybitniejszych wodzów wszech-

${ }^{64}$ Por. przypis 28.

${ }^{65}$ Por. J. A. Gierowski, Rzeczpospolita w dobie złotej wolności (1648-1763), Kraków 2001, s. 161. 
czasów $^{66}$. W tym samym źródle Niemiec zwrócił również uwagę na fakt, że polski król był naczelnym wodzem wojsk sprzymierzonych, które stłumiły potęgę państwa tureckiego i prawdopodobnie ocaliły Europę środkową i zachodnią od ciągłych wojen z Turcją ${ }^{67}$.

Obecność w Wiedniu 19 nazw ulic upamiętniających wybitne osobistości z polskiego świata kultury i polityki może sprawiać wrażenie, że nasi rodacy w znaczący sposób wpisali się w historię życia umysłowego tego miasta. Jednakże "polskie” ulice w tak dużej metropolii jak stolica dawnej Monarchii Naddunajskiej, gdzie co krok historia splata się ze współczesnością, absolutnie nie rzucają się w oczy na tle innych podobnych miejsc pamięci. O proporcjach ilościowych omawianych "polskich” pamiątek dobitnie świadczy procent ulic, które są nazwane na cześć naszych rodaków (19), w porównaniu z całkowitą ilością ulic w Wiedniu (około 6 982). Dla porównania, ciekawym w tym miejscu wydaje się pokrótkie zbadanie, ile osobistości pochodzących z innych krajów niż obszar rdzennej Austrii uczczono ulicami w tej metropolii ${ }^{68},{ }^{69}$. Okazuje się, że osoby urodzone na terenie Czech i Moraw są uczczone aż 92-ma nazwami ulic, Włoch - 47ma, Węgier - 25-ma. Ponadto upamiętnionych zostało 19 osób pochodzących z krajów bałkańskich - Słowenii i Chorwacji, 15 osobistości z Francji, 9 - z Rosji i Ukrainy, 8 / 9 z Wielkiej Brytanii, 7 ze Szwecji, 6 / 7 z USA, 3 - z Niderlandów, oraz po dwie znakomitości z Rumunii i z Hiszpanii. Po jednej ulicy upamiętnia osoby, które urodziły się w Danii, Finlandii, Mołdawii, Norwegii, a nawet Portoryko ${ }^{70}$. Wiedeńczycy uczcili oczywiście głównie te osobistości, których ojczyzny - w przebiegu dziejów - były częścią Monarchii Habsburgów. Dane ilościowe dotyczące ulic w większości przypadków w ogólnych zarysach pokrywają się z faktem

${ }_{66}$ Por. C. von Clausewitz, Hinterlassene Werke, Tom 5, Berlin 1837, s. 4-7.

${ }^{67} \mathrm{Ibidem}$. Na pomniku odsieczowym w katedrze św. Szczepana wymienione były również nazwiska kilku innych Polaków, którzy wyróżnili się w bitwie wiedeńskiej. Byli to: hetman wielki koronny Stanisław Jabłonowski, Henryk Lubomirski oraz Hieronim Sieniawski. Por. A. Gubrynowicz, Pamiątki polskie w Wiedniu i okolicy, „Kurier Warszawski", 1926, nr 216.

68 Zestawienie to jest opracowane według miejsca urodzenia danej osobistości. Jest to klucz niedoskonały, jednak w obliczu skomplikowanej sytuacji narodowościowej Monarchii trudno o lepszy. Lista może być nie do końca pełna. Zostały wybrane osoby o nazwiskach nie niemiecko brzmiących. Materiałem do dalszych badań może być sprawdzenie pod tym kątem niemiecko brzmiących nazwisk wiedeńskich patronów ulic.

${ }_{69}$ Miejsca urodzenia zostały zaklasyfikowane do tego kraju, do jakiego należały w okresie życia wymienionych osób. Oczywiście ówczesne granice nie muszą pokrywać się z dzisiejszymi granicami państw.

${ }^{70}$ Lista nazw ulic może być niepełna. Do zestawienia zostały wybrane nazwy ulic, których patroni nosili nie niemiecko brzmiące nazwiska. Nie można wykluczyć, że w tym gronie mogłyby się znaleźć osoby o nazwiskach niemiecko brzmiących. 
długoletnich związków terytorialnych danego kraju z Monarchią Naddunajską ${ }^{71}$. Osobistości urodzone na terenie Polski, uczczeni 19-ma nazwami ulic, wpisują się w powyższy schemat. Jednak w tak prestiżowym mieście europejskim powinna cieszyć już sama obecność polskich śladów, do których można nawiązywać, podając jako przykład dawnej świetności i swoisty drogowskaz dla innych. Ponadto oczywistym jest fakt, że o wyborze postaci uczczonej pamiątką decyduja poza tendencjami historyczno-kulturowymi epoki, również osobiste upodobania osób proponujących nadanie takiej a nie innej nazwy nazwy. Wielu słynnych Polaków, m.in. przedstawicieli świata kultury i polityki, którzy odnieśli sukces w Wiedniu, niewątpliwie zasługuje na uczczenie ich pamięci w tym mieście $\mathrm{w}$ nie mniejszy sposób aniżeli osobistości, których imiona zostały już upamiętnione. Nadzieję w tym względzie może budzić fakt, że na uczczenie niektórych wybitnych polskich osobistości Wiedeńczycy również kazali długo czekać: przykładowo nazwa ulicy i placu Sobieskiego została nadana po 166 latach, Kulczyckiego ${ }^{72}$ - po 168 latach, a Kopernika - aż po 324 latach od śmierci patrona. Być może więc również inni sławni Polacy doczekają się kiedyś upamiętnienia ich życia i działalności w tej cesarsko-królewskiej metropolii.

\title{
Zusammenfassung
}

\author{
“<EINEN WIENER VERBINDET VIEL MEHR \\ MIT EINEM KRAKAUER ODER BUDAPESTER \\ ALS MIT EINEM BERLINER $>$. DIE REZEPTION \\ DER POLNISCH-ÖSTERREICHISCHEN BEZIEHUNGEN \\ AUF GRUND DER “POLNISCHEN" STRASSENNAMEN IN WIEN"
}

Wien ist eine Metropole, deren Charme und Vielseitigkeit auch von Polen mit geprägt wurde: Frederic Chopin, Johann Kiepura, Bronislaw Huberman, Thaddeus Rittner u. v. a. wirkten als gebürtige Polen in Wien. Als Mittelpunkt des Habsburger Reichs war

${ }^{71}$ Morawy i Czechy stały się częścią Monarchii w roku 1526 i pozostały jego częściami do roku 1918. Dzisiejsze Włochy były podzielone na kilka mniejszych państw, z których w skład Monarchii wchodziły m.in.: Lombardia (1714-1859), Parma (1735-1746, 18151847), Modena (1814-1860), Wenecja (1815-1866). Północna część Węgier weszła w skład monarchii w roku 1526, w 1699 Siedmiogród, a w 1718 pozostała część Węgier - Banat. W 1699 ziemiami Monarchii stały się na południu tereny do rzeki Sawy, czyli duża część Słowenii i Chorwacji. Por. H. Wereszycki, Historia Austrii, Wrocław / Warszawa / Kraków 1996, s. 266 i dalej, 277 i dalej, 282 i dalej.

72 Kurier podczas odsieczy w roku 1683, według legendy - założyciel pierwszej wiedeńskiej kawiarni, co niestety mija się z prawdą. Por. W. Kleindel, Österreich - Daten zur Geschichte und Kultur, Wien 1994, s. 234; G. Gugitz, Das Wiener Kaffeehaus, Wien 1914, s. 12. 
die Stadt seit Jahrhunderten Magnet und kulturell-politisch-wirtschaftliches Zentrum des Vielvölkerstaats. Auch Polen fühlten sich seit alters her dort wohl. Die Meissen kamen zwischen 1772 und 1918, als Galizien ein Teil der Donaumonarchie war. Viele von ihnen haben sichbare Spuren hinterlassen, u. a. 19 „polnische” Straßennamen. Im Artikel werden die bekannten und die weniger bekannten Vertreter der Kultur und Politik polnischer Herkunft zusammengestellt, die das öffentliche Leben der letzten Jahren der Habsburger Monarchie mit prägten. 